Információközvetítés és közösségépítés - multifunkciós könyvtári hálózatok.

Szerk. Kiszl Péter, Németh Katalin. Budapest, ELTE BTK

Könyvtár- és Információtudományi Intézet. 2020. 189-202.

\title{
A KÖNYVTÁR HASZNA \\ AZ EGYES DEMOGRÁFIAI VÁLTOZÓK ALAPJÁN
}

\author{
TÓTH MÁTÉ
}

\section{TARTALMI ÖSSZEFOGLALÓ}

A jóléti rendszerekben állandóan felmerülő kérdés, milyen mértékben és kiknek a körében hasznosulnak a közpénzböl fenntartott szolgáltatások. A 2017-es országos reprezentatív olvasás és könyvtárhasználati felmérés adatai alapján arra keresem a választ, hogy a lakosság egyes szegmensei milyen formában és milyen mértékben profitálnak a könyvtárak szolgáltatásaiból.

A tanulmány a Fővárosi Szabó Ervin Könyvtár (FSZEK) EFOP-3.3.3-VEKOP-162016-00001 „Múzeumi és könyvtári fejlesztések mindenkinek” pályázati konstrukció keretében lefolytatott kérdőíves vizsgálat egyetlen kérdésének válaszait összegezi a különböző demográfiai változók (nem, életkor, iskolai végzettség, lakóhely típusa) szerint.

Megállapítottuk, hogy a könyvtár hasznosulása messze túlmutat azokon a hagyományos funkciókon, amelyeket jellemzően hangsúlyozni szoktunk (információközvetítés, tanulás támogatása, olvasás, kultúraközvetítés), ráadásul az egyes demográfiai jellemzők alapján felállított csoportok eltérő mértékben és formában profitálnak az intézményrendszer szolgáltatásaiból.

\section{Bevezetés}

A könyvtárosok munkájára szívesen hivatkozunk úgy, mint az egyik legrégibb foglalkozások egyikére, a könyvtárakra pedig mint a legrégebben fennálló intézményrendszerre. A publikált tudás teljességének megőrzése már az ókortól kezdve fontos szempont volt, ezért a gazdag és fejlett államok nem kímélték az anyagiakat azokra a méltán híressé vált intézményekre, amelyek egy-egy közösség emlékezetének megőrzésére hivatottak. A könyvtárak hosszú története során azonban állandóan változtak azok a szerepek, amelyeket ezek az intézmények betöltöttek az adott korszak társadalmában.

Napjainkban a közpénzből fenntartott könyvtárak hasznosulását két oldalról lehet megközelíteni:

1. egyrészt a közösség oldaláról - ha azt vizsgáljuk, hogy az adott társadalom milyen formában profitál a szolgáltatásokból,

2. másrészt pedig az egyének oldaláról, amikor az egyes polgárok személyes életében meglévő hasznosulást vetjük vizsgálat alá.

A két megközelítésnek vannak közös pontjai és vannak olyanok is, amelyek csak az egyik vagy csak a másik oldalon bírnak jelentőséggel. A nemzeti identitás szempontjából jelentős kincsek (pl. a Corvina kódexek) megőrzése a nemzet közösségének na- 


\section{Tóth MÁTÉ}

gyon fontos, míg az egyének csak nagyritkán látják ennek közvetlen hasznát a saját életükben (pl. egy kiállítás alkalmával, amikor meg lehet tekinteni ezeket a könyveket). Másik oldalról viszont az egyén is profitálhat a könyvtárak szolgáltatásaiból olyan területeken, amelyek a közösség számára marginális jelentőségűek (pl. a szabadidő eltöltése). A jóléti társadalmakban azonban a két szempont erősen összefügg egymással.

„Jóléti államnak szokás nevezni azoknak a jóléti programoknak az együttesét, amelyeken keresztül az állam messzemenően gondoskodik polgárainak jólétéről. A jóléti államok a második világháború után fejlődtek ki Nyugat-Európában. Az általuk nyújtott támogatások méretei és konkrét típusai is meglehetősen eltérőek." Amennyiben az egyén életében hasznosul egy adott szolgáltatás, akkor - tekintve, hogy a jóléti állam célja, hogy gondoskodjon a polgárainak jólétéről - az a közösség számára is fontos.

Ebben a tanulmányban azt vizsgálom meg a 2017-es országos reprezentatív olvasási és könyvtárhasználati felmérés kapcsán, hogy a lakosság egyes szegmensei milyen formában profitálnak a könyvtárak szolgáltatásaiból. Egyetlen kérdés válaszait fogom összegezni különböző demográfiai változók (nem, életkor, iskolai végzettség, lakóhely típusa) mentén, hogy megtudjuk, mely csoportoknak miért jelent sokat a könyvtári rendszer.

A könyvtár szándékai szerint esélyegyenlőséget teremt a kulturális javakhoz való hozzáférés terén, ugyanakkor a könyvtárszociológiai mérések alapján már évtizedek óta tudjuk, hogy azok veszik igénybe leginkább a könyvtári szolgáltatásokat, akik egyébként is bőségesen rendelkeznek ezekkel a javakkal. ${ }^{2}$ A könyvtárak hasznosulására vonatkozó kérdés demográfiai változók alapján képzett csoportonként való elemzésével egy-egy konkrét terület kapcsán is kimutathatóvá válik, hogy kik és milyen mértékben profitálnak az intézményrendszerünk szolgáltatásaiból.

\section{Módszer}

Elemzésemet a fent említett - Fővárosi Szabó Ervin Könyvtár (FSZEK) EFOP-3.3.3VEKOP-16-2016-00001 Múzeumi és könyvtári fejlesztések mindenkinek pályázati konstrukció keretében $A z$ én könyvtáram című kiemelt projektben lefolytatott országos reprezentatív kutatások alapján készítettem.

Az utóbbi kutatás módszereit és feltételrendszerét 2018-ban már bemutattam egy gyorsjelentésben ${ }^{3}$, ezért most csak a legfontosabb paramétereket említem. 1500-1500 fös reprezentatív mintán kérdeztük meg a hazai 18 éven felüli és a 3-18 éves lakosságot az olvasási és könyvtárhasználati szokásairól. A többlépcsős, arányosan rétegzett valószínűségi mintavételi eljárás biztosította a reprezentativitást, nemek, életkorok, lakóhely, lakóhely típusa és iskolai végzettség szempontjából. A mintában szereplő válaszadók véletlenszerüen kerültek kiválasztásra, ugyanakkor az eltérő válaszadási 
hajlandóság és a véletlenszerüségből fakadó bizonytalanság miatt a felvett adatokat a cég munkatársai súlyozással korrigálták a KSH 2016-os mikrocenzus alapján. ${ }^{4}$

A kérdés, amelynek válaszai alapján a jelenlegi cikk készült, úgy hangzott, hogy „Az élet mely területén veszi/vette hasznát a településén lévő (városi, kerületi, községi) könyvtár által nyújtott szolgáltatásoknak, információnak? (Az elektronikus szolgáltatásokra is gondoljon!)”. Ezt a kérdést csak a felnőtteknek tettük fel.

A kérdést egy nemzetközi (finn, holland és norvég) összehasonlító kutatásból vettük át. A kérdés azt feltételezi, hogy a könyvtár igen sokféle területen hasznosulhat. ${ }^{5}$ Például, ha valaki a könyvtárból veszi kölcsön az útikönyvet, amelyet a nyaralásnál használ, akkor ő utazáshoz használta a könyvtárat. Ha valaki a gyerekét a könyvtárban hagyja, amíg ő maga elintézi a hivatali ügyeit, akkor a gyermeknevelés, gyermekmegőrzés területén hasznosultak számára az intézményeink szolgáltatásai. Ha bárki a könyvtár nyilvános vezeték nélküli hálózatán keresztül foglal színházjegyet, akkor ő más kulturális tevékenységek terén profitált a könyvtárak tevékenységéből.

Kérdéses volt számunkra az is, hogy a válaszadóink egyáltalán képesek lesznek-e ilyen formában értelmezni a kérdést, hiszen mindez a könyvtárnak egy meglehetősen komplex interpretációját feltételezi a válaszadóinktól. Az átlag internet-használó nem is feltétlenül van tisztában azzal, hogy például a világhálón elérhető digitalizált tartalmakat valamely közgyüjtemény tette-e közzé, vagy hogy a város valamely pontján elérhető vezeték nélküli hálózatot mely intézmény biztosítja a számára. Először bemutatom egyben az összes választ, majd a demográfiai jellemzők alapján lebontva külön elemzem a válaszokat öt kiválasztott területen.

\section{Eredmények}

A kérdés megfogalmazásakor bíztunk benne, hogy valamennyi felkínált területen kapunk pozitív válaszokat, illetve feltételeztük, hogy egyes esetekben (pl. tanulás támogatása, szépirodalom olvasása) többen fognak úgy nyilatkozni, hogy profitálnak a könyvtár szolgáltatásaiból, mint a kevésbé egyértelműen ehhez az intézményhez köthető területeken. Az összes válaszadó összesített eredményei megerősítették az előfeltevéseinket (1. ábra).

A lenti diagram elemzésekor az első és legfontosabb megállapítás, amit tehetünk, hogy - bár az embereknek csupán kevesebb, mint 10\%-a könyvtárhasználó - az intézményrendszer hasznosságát, hasznosulását ennél jóval többen érzik, tapasztalják. Igaz ez még akkor is, ha a legtöbb általunk felsorolt szempont alapján a könyvtárak szolgáltatásaiból az emberek 80-90\%-a soha, semmilyen formában nem profitált, vagyis számukra a könyvtár ezeken a területeken nem jelent semmilyen hasznot. 


\section{Tóth MÁTÉ}

A könyvtár hasznosulása az élet egyes területein $(n=1500)$

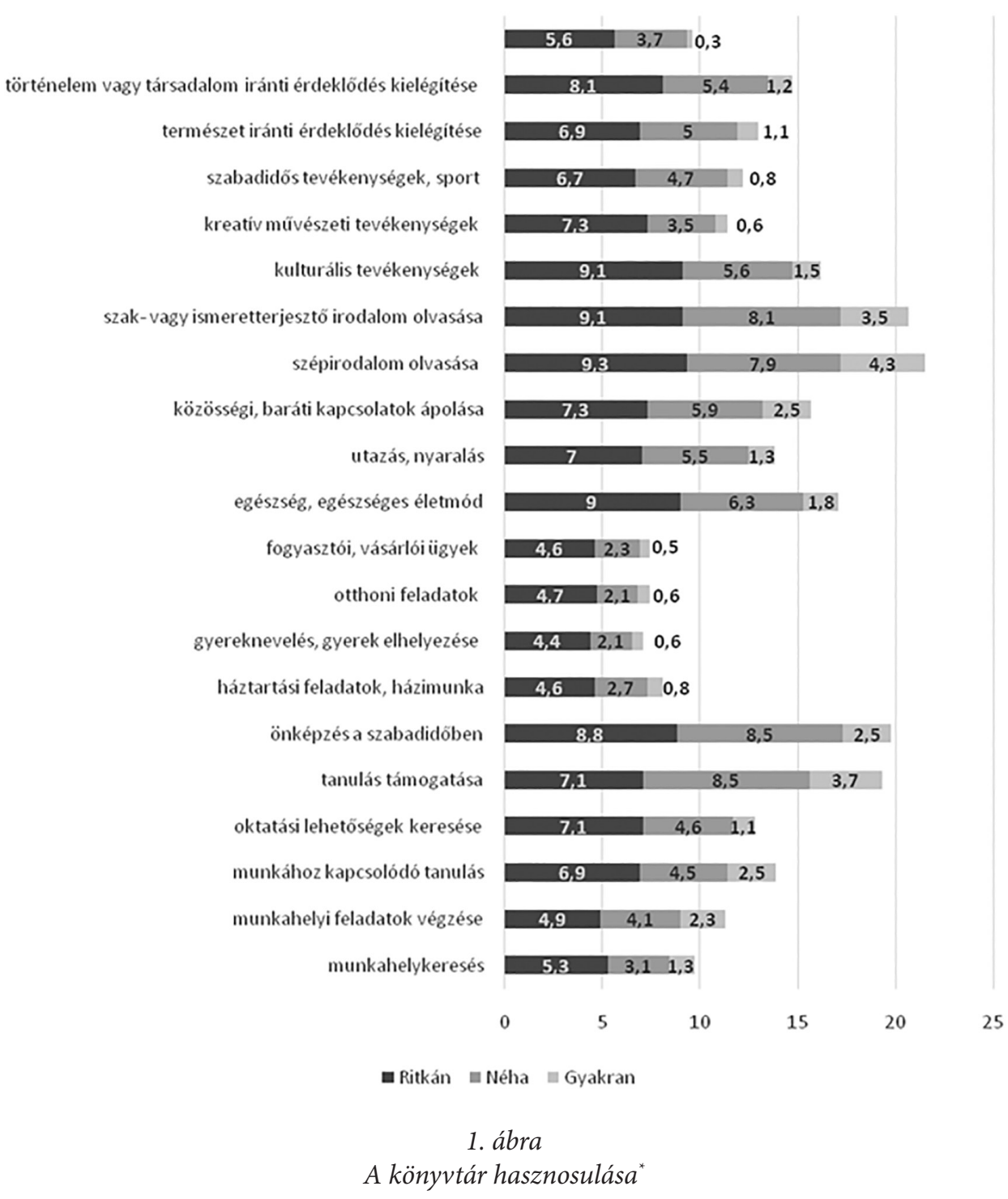

Ha összeadjuk a pozitív válaszokat (azokét, akik ritkán, néha vagy gyakran, de profitálnak a könyvtár szolgáltatásaiból), akkor 20\% fölötti értéket kaptunk a szép$(21,5 \%)$, valamint a szak- vagy ismeretterjesztő irodalom olvasása $(20,7 \%)$ soroknál,

*A tanulmány minden ábráját a szerző készítette. 
és ettől nem sokkal lemaradva jöttek az önképzés a szabadidőben $(19,8 \%)$ és a tanulás támogatása (19,3\%) válaszlehetőségek. Némileg meglepő módon ezeket követi az egészség, egészséges életmód (17,1\%), majd csak azután a kulturális tevékenységek $(16,2 \%)$ és a közösségi, baráti kapcsolatok ápolása. (15,7\%).

Azoknak a területeknek az esetében, amelyeket kevesebben jelöltek meg (gyereknevelés, otthoni feladatok, házimunka), célszerű azt is mérlegelni, hogy ezek mennyire vannak távol vagy közel a könyvtári rendszer közismert funkcióitól. Ezek kapcsán elsősorban arra következtethetünk, hogy az intézményrendszer az eredeti funkcióival kevésbé kapcsolatba hozható területeken is produkál olyan hasznot az olvasóknak, amelyeket a fenntartók és a nagyközönség számára eddig kevésbé kommunikáltunk.

Az eredmények demográfiai bontásban való bemutatását megelőzően érdemes visszatekinteni arra, mely csoportok azok, amelyek eleve gyakrabban járnak könyvtárba, hiszen ők vélhetően nagyobb valószínüséggel nyilatkoznak pozitívan arról, hogy az adott szempont szerint profitáltak-e az intézményrendszer szolgáltatásaiból.

Kizárólag a későbbi adatokkal való összevethetőség miatt közlöm az alábbiakban a 2017. évi országos reprezentatív felmérés eredményeit a könyvtári tagságra vonatkozóan (1. táblázat).

\section{1. táblázat}

Beiratkozott tagja-e Ön, vagy volt-e tagja valamikor valamilyen könyvtárnak?

\begin{tabular}{|l|l|l|l|l|l|}
\hline & $\begin{array}{c}\text { Soha nem volt } \\
\text { könyvtári tag }\end{array}$ & $\begin{array}{c}\text { Most nem, de } \\
\text { régebben az volt }\end{array}$ & Jelenleg tag & $\begin{array}{c}\text { Nem tudjal } \\
\text { Nem válaszol }\end{array}$ & Összesen \\
\hline Férfi & $43,6 \%$ & $48,9 \%$ & $7,4 \%$ & $0,1 \%$ & $100,0 \%$ \\
\hline Nö & $37,6 \%$ & $50,8 \%$ & $11,6 \%$ & $0,1 \%$ & $100,0 \%$ \\
\hline $18-29$ & $35,2 \%$ & $51,5 \%$ & $13,3 \%$ & $0,0 \%$ & $100,0 \%$ \\
\hline $30-39$ & $32,9 \%$ & $56,9 \%$ & $10,2 \%$ & $0,0 \%$ & $100,0 \%$ \\
\hline $40-49$ & $34,4 \%$ & $55,0 \%$ & $10,3 \%$ & $0,4 \%$ & $100,0 \%$ \\
\hline $50-59$ & $36,3 \%$ & $55,3 \%$ & $8,4 \%$ & $0,0 \%$ & $100,0 \%$ \\
\hline $60-x x$ & $52,9 \%$ & $39,7 \%$ & $7,4 \%$ & $0,0 \%$ & $100,0 \%$ \\
\hline Alapfok & $59,0 \%$ & $37,4 \%$ & $3,4 \%$ & $0,1 \%$ & $100,0 \%$ \\
\hline Középfok & $32,5 \%$ & $55,9 \%$ & $11,4 \%$ & $0,2 \%$ & $100,0 \%$ \\
\hline Felsöfok & $12,9 \%$ & $67,0 \%$ & $20,1 \%$ & $0,0 \%$ & $100,0 \%$ \\
\hline Budapest & $31,4 \%$ & $59,6 \%$ & $9,0 \%$ & $0,0 \%$ & $100,0 \%$ \\
\hline Megyeszékhely & $36,8 \%$ & $49,6 \%$ & $13,5 \%$ & $0,0 \%$ & $100,0 \%$ \\
\hline Város & $43,1 \%$ & $48,5 \%$ & $8,2 \%$ & $0,2 \%$ & $100,0 \%$ \\
\hline Község & $45,0 \%$ & $45,7 \%$ & $9,2 \%$ & $0,0 \%$ & $100,0 \%$ \\
\hline Összesen & $40,4 \%$ & $49,9 \%$ & $9,6 \%$ & $0,1 \%$ & $100,0 \%$ \\
\hline
\end{tabular}




\section{Tóth MÁTÉ}

A tipikus könyvtárhasználó tehát fiatal, nagyvárosi, magasan iskolázott nő. Egy felsőfokú végzettségű személy esetében 6-7-szer nagyobb a valószínűsége, hogy az illető könyvtári tag, mint egy alapfokon iskolázott esetében. A férfiak és nök vonatkozásában az arány körülbelül másfélszeres, a 30 év alattiak és a 60 év felettiek közötti arány pedig majdnem kétszeres. Ezeket az arányokat kell észben tartanunk, amikor az alábbi - demográfiai bontásban bemutatott - adatokat elemezzük.

\section{Szépirodalom olvasása}

A szépirodalom olvasása (2. ábra) az a szempont, amelyről a legtöbben nyilatkoztak pozitívan: a válaszadók több mint $21 \%$-a említette, hogy legalább nagyritkán profitál a könyvtárak szolgáltatásaiból ezen a területen. Népszerű sztereotípia, hogy a könyvtár olyan hely, amelyet az olvasni - leginkább szépirodalmat olvasni - szerető emberek látogatnak. A kép demográfiai bontásban tovább árnyalható.

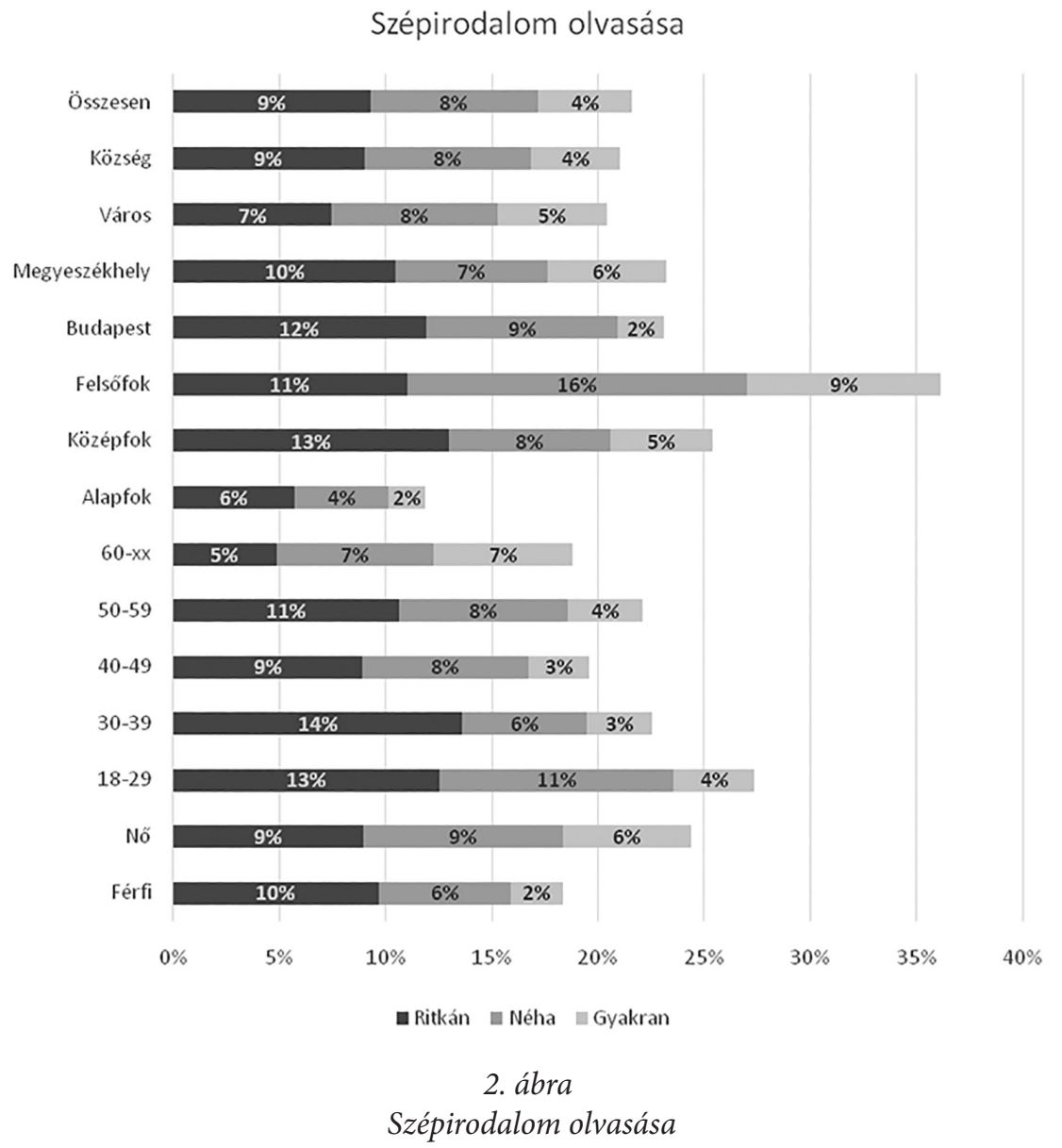


A beiratkozott használók demográfiai összetételével való összevetésben is jól látható, hogy a lakóhely típusa tekintetében nincsenek nagy különbségek: a nagyobb városokban élők azok, akiknek a körében a leginkább hasznosul a könyvtár, mint a szépirodalom olvasásának lehetőségét biztosító intézmény. A budapestiek közül meglehetősen kevés válaszadó, mindössze $2 \%$ jelölte meg a „gyakran” opciót, szemben a megyei jogú városok 6\%-ával. A nagyobb vidéki városokban a könyvtárnak az ilyen irányú használata érezhetően sokkal erősebb, mint Budapesten.

A nemek vonatkozásában azt láthatjuk, hogy a nők nemcsak gyakori könyvtárhasználók, de közülük nagyobb számban vannak azok is, akik gyakran is élnek a szépirodalom olvasás lehetőségével. Életkori tekintetben a 60 év fölöttieket emelném ki, akik ritkán könyvtárhasználók, de az ő körükben a legmagasabb azoknak aránya, akik a "gyakran” opciót választották ebben a kérdésben. Az idősebb emberek használják a könyvtárat a leginkább a tradicionális funkciók mentén.

$\mathrm{Az}$ iskolai végzettség vonatkozásában a leginkább szembeötlő, hogy az alapfokú végzettségüek között (akiknek a körében csak 3,4\% a beiratkozott tag), milyen sok válaszadó, $12 \%$ említette, hogy szokta használni a könyvtárnak ezt a funkcióját, szemben a felsőfokú végzettségűekkel, ahol az alig több mint $20 \%$ beiratkozott használóval szemben $34 \%$ nyilatkozott pozitívan a szépirodalom olvasása kapcsán.

\section{Tanulás támogatása}

A második legnépszerủbb opciók a tanulás támogatásával voltak kapcsolatosak, a válaszadók közel 20\%-a foglalt állást pozitívan abban a kérdésben, hogy hasznosul-e az életében a könyvtár, mint tanulást és önképzést támogató intézmény.

Az egyes csoportok vizsgálata során nem meglepő, hogy a 30 év alatti fiatalok voltak azok, akik a legmagasabb arányban adtak pozitív választ erre a kérdésre. Rajtuk kívül - szintén nem meglepő módon - a felsőfokú végzettségűek voltak, akiknek az életében jobban hasznosul a könyvtár, mint tanulást támogató intézmény. 
TóTh Máté

\section{Tanulás támogatása}

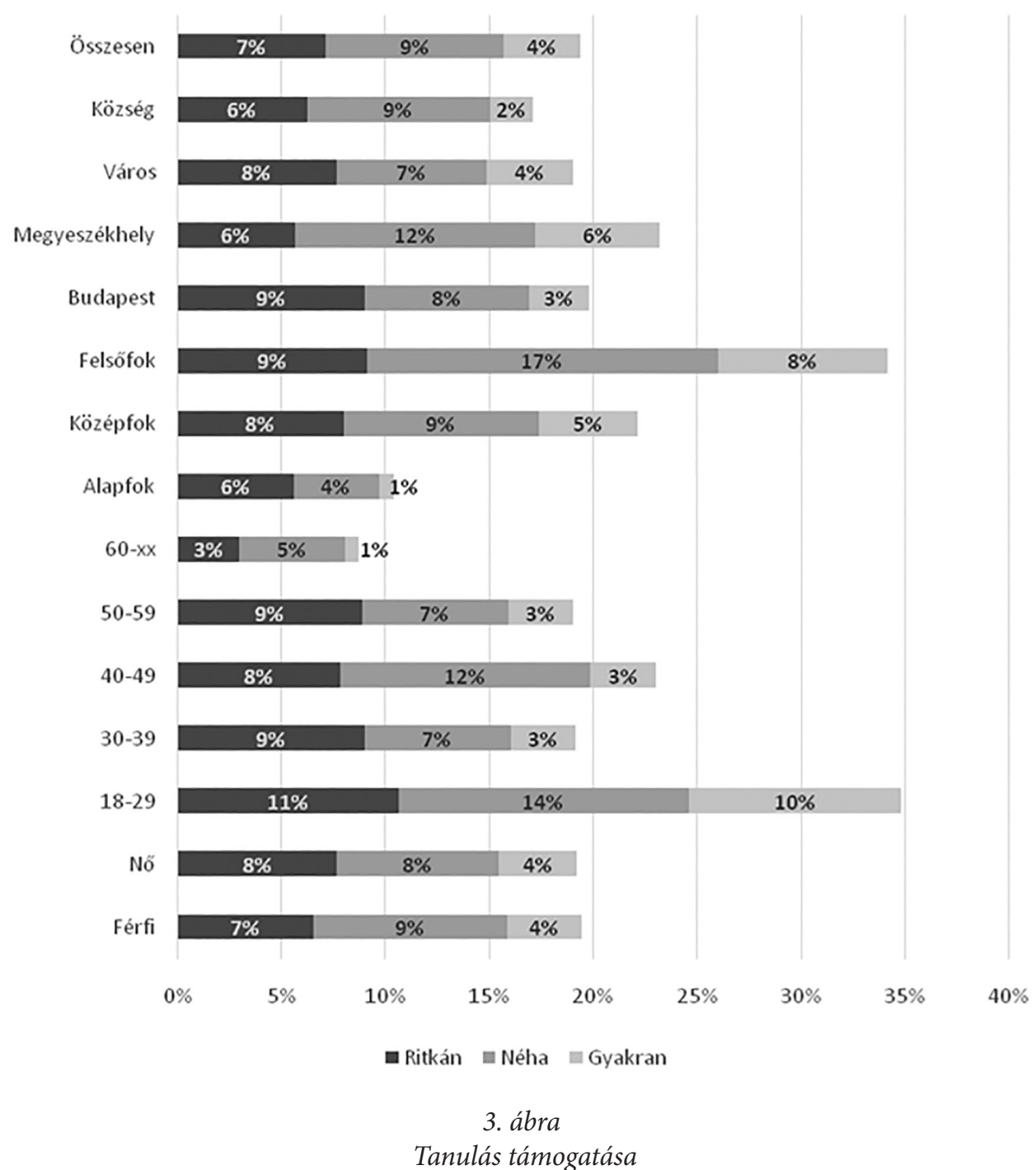

A 3. ábrán a leginkább szembetünő jelenség, hogy bár a férfiak körében kisebb arányban vannak a könyvtárba beiratkozottak, mégis ugyanannyian vannak, akik használják azt tanulásra, sőt kevéssel nagyobb arányban vannak azok, akik nem csak nagyritkán teszik ezt. Ez azt jelenti, hogy a férfiak körében - a nőkhöz képest - arányaiban többen vannak, akik tanulási célból veszik igénybe a könyvtárakat. 
Munkahelyi feladatok végzése

A könyvtárra sokan úgy tekintenek, mint a város dolgozószobájára, ahol rendelkezésre áll a megfelelő infrastruktúra akár munkahelyi feladatok végzéséhez is. A könyvtár mint közösségi iroda téma is népszerü a külföldi szakirodalomban, ${ }^{6}$ hiszen minden irodai funkció adott a közkönyvtárakban. A szépirodalom olvasásához és a tanulás támogatásához képest jóval kevesebben, mindössze 11\% nyilatkozta, hogy hasznosul számára a könyvtár a munkahelyi feladatai végzése során is (4. ábra).

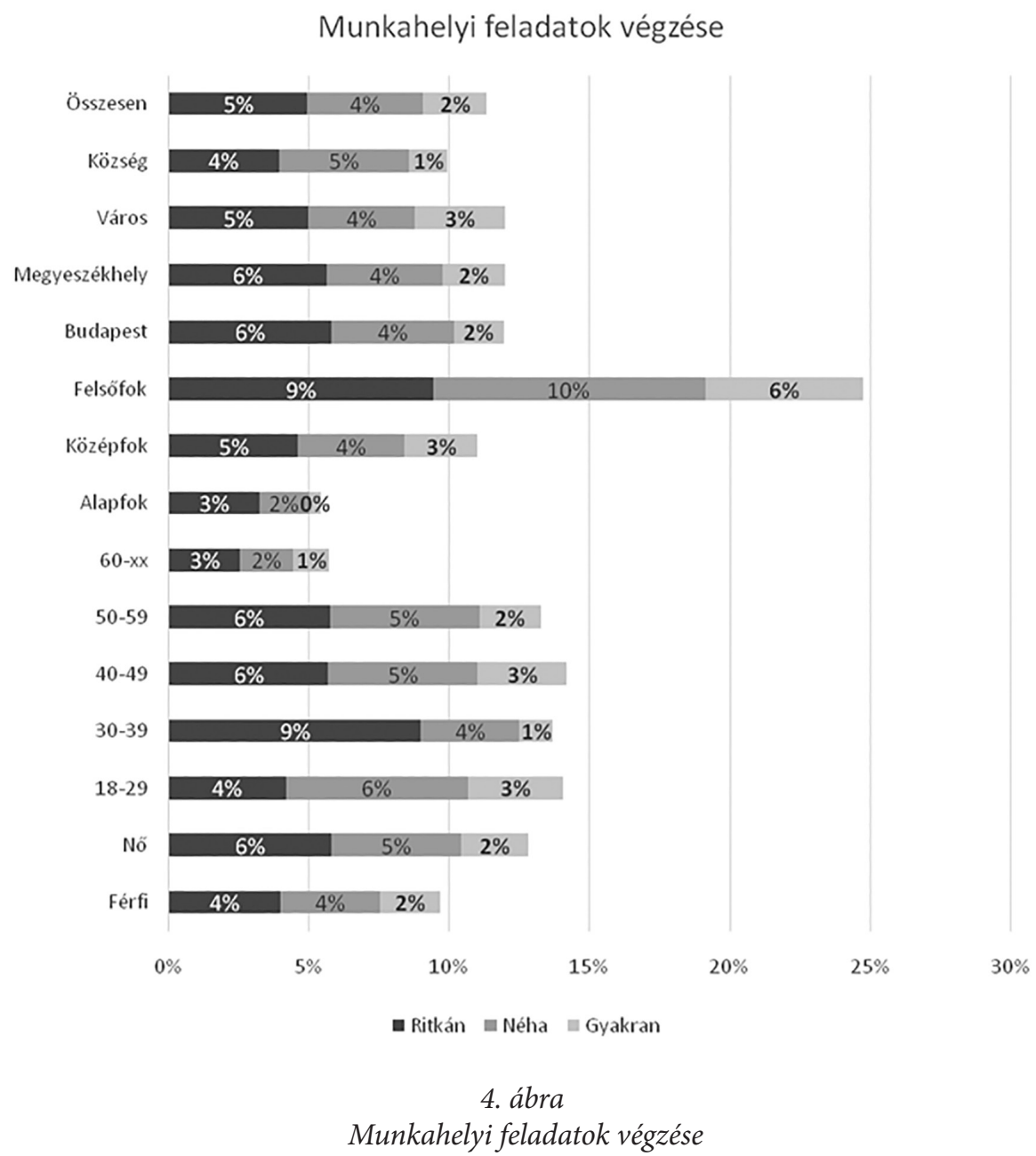

Nem meglepő, hogy a munkahelyi feladatok tekintetében a felsőfokú végzettségüek, és az aktív dolgozó korosztály (18-60 év) is kiemelkednek a többi demográfiai csoporthoz képest, a nemek, valamint a településtípus szerinti belső arányok tükrözik 


\section{Tóth MÁTÉ}

a könyvtári tagokét általában. Azaz több nő jár a könyvtárba, és ezért lettek többen közülük, akik használják a könyvtárat munkahelyi feladatok végzésére is.

\section{Otthoni feladatok}

A kérdőívbe több olyan terület is bekerült, amelyek nem tekinthetők tipikusnak a könyvtári szolgáltatások hasznosulásában (például utazás, nyaralás, gyermekmegörzés, egészség, egészséges életmód stb.), ugyanakkor ezek is fontosak lehetnek az életminőség javításában. Ha valaki a könyvtári interneten fizeti be a számláit, ott rendeli meg az online bevásárlást, akkor ezen a területen hasznosult számára a könyvtár. Ugyanez elmondható, ha a könyvtár tájékoztatószolgáltatásán keresztül szerez információt árakról, könyvtárból kölcsönzött könyvekből tájékozódik kertészkedésről vagy otthoni villanyszerelésről. A könyvtárak otthoni feladatokkal kapcsolatos hasznosulását mutatja az 5. ábra.

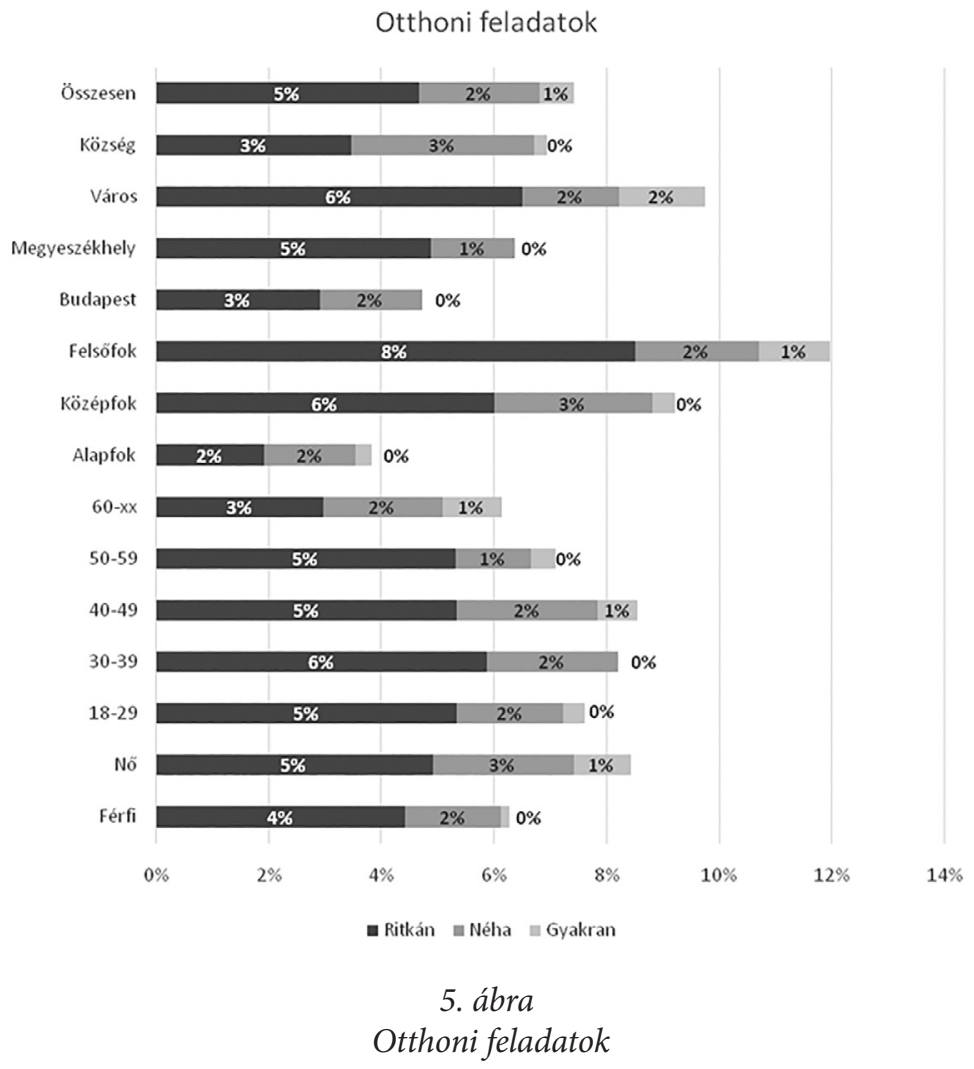

A beiratkozottak arányához képest jelentős eltéréseket a településtípus vonatkozásában regisztrálhatunk. A kisebb városokban válaszolták a legnagyobb arányban azt, hogy 
ritkán, néha vagy gyakran hasznosul számukra a könyvtár az otthoni feladatok végzése során is. A pozitívan válaszolók ott voltak sokan, ahol a beiratkozottak aránya a legalacsonyabb a teljes lakosság körében. Ezzel szemben Budapesten vannak a legkevesebben, akiknél a könyvtár hasznosul ebben a vonatkozásban. Életkor, nem és végzettség tekintetében nem találtunk jelentős eltéréseket a beiratkozottak arányához képest.

\section{Közösségi és baráti kapcsolatok ápolása}

A könyvtár mint közösségi tér, harmadik hely vagy találkozóhely népszerü témái az elmúlt évek szakirodalmának. A kérdőívben egyetlen terület jelent meg erre vonatkozóan: a közösségi és baráti kapcsolatok ápolása (6. ábra). Az erre a területre pozitívan válaszolók aránya alatta marad a hagyományos könyvtári funkciókra vonatkozóknak (pl. tanulás, szépirodalom olvasása), mégis a beiratkozottakhoz képest többen (15\%) nyilatkoztak úgy, hogy ebben a vonatkozásban is hasznosulnak számára a könyvtári szolgáltatások.

Közösségi és baráti kapcsolatok

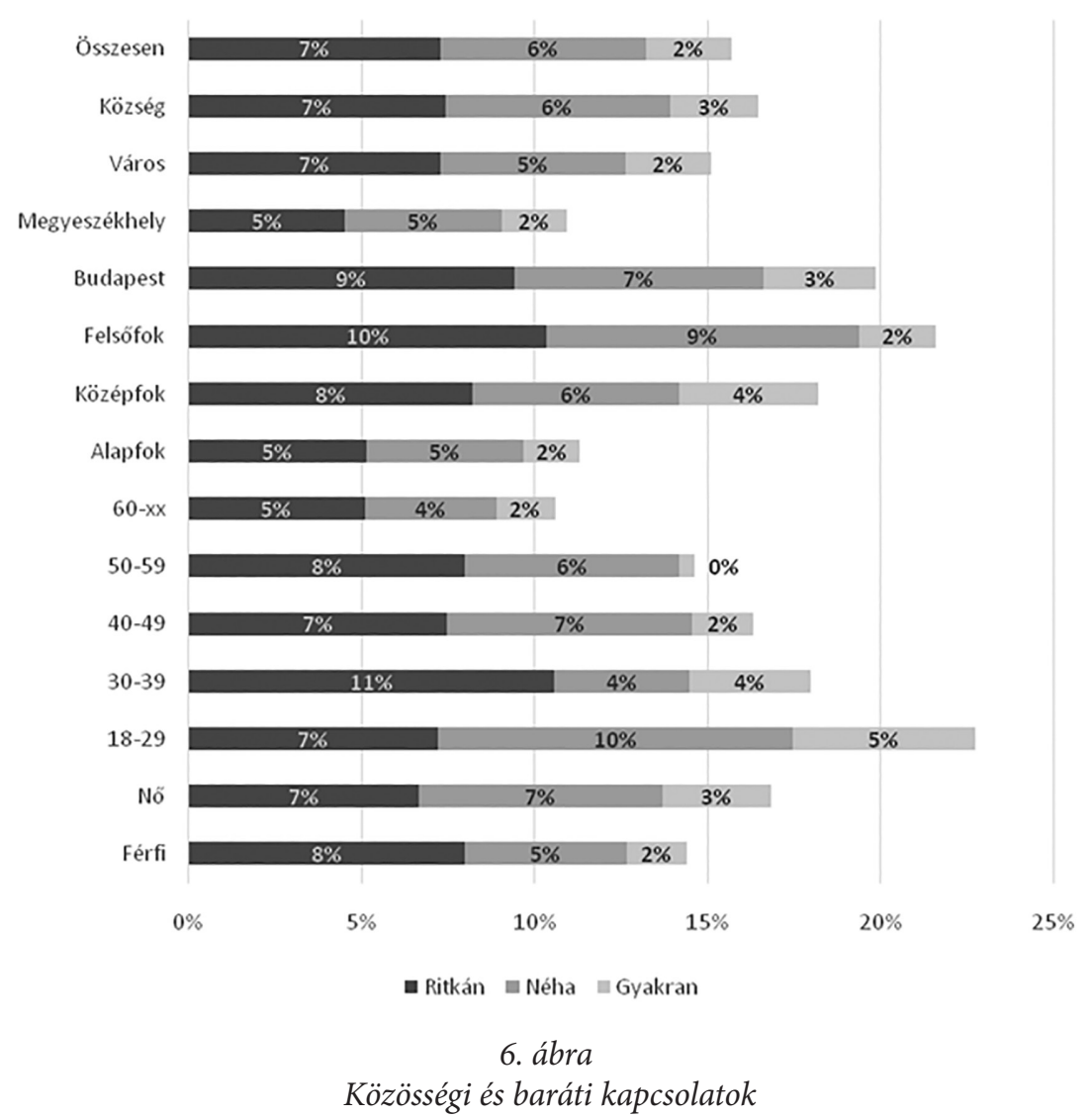




\section{Tóth MÁTÉ}

Ez az első olyan terület, amelyben nincs többszörös különbség az alap- és a felsőfokú végzettségűek válaszai között. Míg az előbbiek körében 12, utóbbiak esetében kevesebb, mint a duplája (21\%) nyilatkozott pozitívan ebben a kérdésben. Ami szintén figyelemre méltó, hogy a „gyakran” opciót választók ugyanannyit, 2-2\%-ot tesznek ki mindkét körben. A beiratkozott használókhoz képest tehát kijelenthető, hogy az alapfokú könyvtárhasználók körében többen vannak, akiknek az életében ilyen formában is hasznosul a könyvtár.

Az eddigiekhez és a beiratkozott látogatók arányához képest ezen a területen a lakóhely típusa jelent leginkább meghatározó különbséget. A megyei jogú városokban vannak a legnagyobb arányban könyvtári tagok, mégis itt vannak a legkevesebben, akik azt válaszolták, hogy a társasági és baráti kapcsolatok ápolásában hasznosulnak számukra a könyvtári szolgáltatások. Ezzel szemben Budapesten, a községekben és a kisebb városokban, ahol a könyvtári tagok aránya az országos átlag alatt van, többen foglaltak állást pozitívan ebben a kérdésben. A budapestiek mellett a fiatalok azok, akiknek a körében kiemelkedően magas azoknak az aránya, akik baráti kapcsolatok ápolásában is hasznát veszik a könyvtári szolgáltatásoknak.

\section{Összegzés}

A 2017-es országos reprezentatív olvasás és könyvtárhasználati felmérés egy kérdésére adott válaszainak demográfiai csoportok szerinti bontásban való bemutatásával az volt a célom, hogy választ kapjunk a kérdésre: a könyvtár kiknek a körében és milyen formában hasznosul. Előzetesen tudtuk, hogy a tipikus könyvtárhasználó magasan iskolázott, fiatal, nagyvárosi nő, így okkal feltételeztük, hogy ebben a körben vannak azok is, akik a legtöbb általunk felvetett szempontból hasznosnak ítélik a könyvtárak tevékenységét. Feltételeztük azonban, hogy vannak bizonyos csoportok, akik a könyvtárat más és más szerepben veszik használatba, akiknek a körében egyegy típusú szolgáltatás, funkció, tevékenység, szerep kiemelten fontos.

Demográfiai csoportok vonatkozásában bátran kimondhatjuk, hogy a könyvtár elsősorban a felsőfokú végzettségüeké. Nem csak ők azok, akiknek a körében a legmagasabb a beiratkozottak aránya, de a könyvtárnak azok a hagyományos funkciói, mint a tanulás támogatása vagy a szépirodalom olvasása is, az ő körükben hasznosulnak a leginkább. Az alapfokú végzettségüek körében a közösségi és baráti kapcsolatok ápolása magasabb, mint amit előzetesen várhattunk volna a könyvtári tagság arányai alapján.

Nemek tekintetében nem regisztrálhattunk igazán markáns különbségeket. A férfiak a tanulás támogatása, a nők pedig a szépirodalom olvasása terén nyilatkoztak többen úgy, hogy hasznosul számukra a könyvtár.

A település típusa azokban az esetekben fontos, ahol a hasznosulás feltételez egyfajta életstílust. Az általunk bemutatottak esetében ilyen volt az otthoni feladatok végzése és a baráti, közösségi kapcsolatok ápolása. A könyvtár leginkább Budapesten funkcionál 
baráti kapcsolatok ápolására szolgáló helyként. Ahogyan a nemzetközi szakirodalomban is elsősorban metropoliszok kapcsán említik a közösségi funkciót, a mi adataink is elsősorban azt erősítik meg, hogy egy világvárosban tud igazán érvényesülni a könyvtáraknak ez a szerepe. Az otthoni feladatok végzésére ezzel szemben inkább a kisebb települések, kisebb városok lakosai használják nagyobb arányban a könyvtárakat.

Összességében megállapíthattuk, hogy a könyvtár hasznosulása messze túlmutat azokon a hagyományos funkciókon, amelyeket jellemzően mi magunk is hangsúlyozni szoktunk (információközvetítés, tanulás támogatása, olvasás, kultúraközvetítés), ráadásul az egyes demográfiai jellemzők mentén felállított csoportok eltérő mértékben és formában profitálnak az intézményrendszer szolgáltatásaiból.

\section{Irodalom és jegyzetek}

1. ANDORKA Rudolf: Bevezetés a szociológiába. Budapest, Osiris Kiadó. 2006. Forrás: https://www.tankonyvtar.hu/hu/tartalom/tamop425/2011_0001_520_bevezetes_a_ szociologiaba/apas10.html [2019. június 25.]

2. GEREBEN Ferenc: Könyv, könyvtár, közönség. (A magyar társadalom olvasáskultúrája olvasás- és könyvtárszociológiai adatok tükrében). Budapest, Országos Széchényi Könyvtár, 1998.; GEREBEN Ferenc: Olvasás- és könyvtárszociológiai vizsgálatok Magyarországon. In: Horváth Tibor - Papp István (szerk.): Könyvtárosok kézikönyve. 4. Határterületek. Budapest, Osiris Kiadó, 2005. 17-49. p.

3. TÓTH Máté: A magyar lakosság olvasási és könyvtárhasználati szokásai 2017-ben. Gyorsjelentés egy országos reprezentatív lakossági felmérés eredményeiből. = Könyvtári Figyelö, 64. évf. 1. sz. 2018. 45-60. p.

4. A kérdőíves felmérések módszertanát és lebonyolítását részletesen bemutatja a Psyma Hungary Kft. által készített két gyorsjelentés. A felnőtt lakosság olvasási és könyvtárhasználati szokásai (Közvélemény-kutatási tevékenység az EFOP-3.3.3-VEKOP/162016-00001 pályázati konstrukció keretében) Gyorsjelentés. Psyma Hungary Kft. 2017. október 5.; A 3-17 éves gyerekek olvasási- és könyvtárhasználati szokásai (Közvélemény-kutatási tevékenység az EFOP-3.3.3-VEKOP/162016-00001 pályázati konstrukció keretében). Gyorsjelentés. Psyma Hungary Kft. 2017. október 5.

5. VAKKARI, Pertti - AABØ, Svanhild - AUDUNSON, Ragnar - HUYSMANS, Frank OOMES, Marjolein: Perceived outcomes of public libraries in Finland, Norway and the Netherlands. = Journal of Documentation, 70. vol. 5. no. 2014. 927-944. p. Forrás: https://doi.org/10.1108/JD-06-2013-0072 [2019. július 1.]

6. BOGNÁR Noémi Erika: Közösségi iroda a könyvtárban. = Könyvtárak új szerepben, innovatív szolgáltatások. K2 Kísérleti mühely. Budapest, Országos Széchényi Könyvtár, 2017. november 30. Forrás: Forrás: https://videotorium.hu/hu/recordings/18321/k2bognar-noemi-erika-kozossegi-iroda-a-konyvtarban [2019. június 25.] 


\section{Tóth MÁTÉ}

Tóth Máté 2003-ban magyar nyelv és irodalom szakos bölcsészként és könyvtárosként végzett az ELTE BTK-n, majd 2015-ben gazdaságinformatikusként a Budapesti Corvinus Egyetemen. 2010-ben az ELTE BTK Könyvtártudományi Doktori Programján szerzett PhD fokozatot. Jelenleg a Könyvtári Intézet Kutatási és Szervezetfejlesztési Osztályának vezetője, valamint a PTE BTK Humán Fejlesztési és Müvelődéstudományi Intézet Könyvtár és Információtudományi Tanszékének adjunktusa.

ORCID: 0000-0003-4529-237X 